\title{
Lingkungan Toko Terhadap Kepuasan Konsumen Dalam Berbelanja
}

\author{
Brahma Wahyu Kurniawan \\ Dosen Universitas Kadiri (UNISKA) \\ Jl Sersan Suharmadji 38 Kediri \\ brahmawahyu@gmail.com
}

\begin{abstract}
The results of this study are as follows: (1) location of the store has a significant influence on consumer satisfaction in shopping, with a value of $\beta=0.590$; (2) The layout of the store has a significant influence on consumer satisfaction in shopping, with a value of $\beta=$ 0.241 ; (3) The atmosphere shop has a significant influence on consumer satisfaction in shopping, with a value of $\beta=0.343$; (4) Simultaneously, store environment variables consisting of store location, store layout and atmosphere of the store has a significant impact on consumer satisfaction in shopping, with a value of $F=$ 86.482 and the value of Adjusted $R$ Square of 0.721. Of these three variables, the location of the store is the dominant variable that affects customer satisfaction in shopping.
\end{abstract}

Keywords: Store environment, consumer satisfaction

\section{PENDAHULUAN}

Dunia perdagangan pada saat ini semakin berkembang, terbukti dengan banyaknya jumlah pasar swalayan dan usaha ritel sejenis yang beroperasi di pusat-pusat kota maupun di daerah-daerah yang dari hari ke hari semakin menarik minat konsumen. Keadaan ini hampir menggeser posisi pasar tradisional yang sudah lama berdiri. Karena pengusaha ritel hampir melakukan segala cara untuk menarik konsumen sebanyak-banyaknya.

Munculnya konsep one stop shopping dalam berbelanja, menyebabkan departemen store atau swalayan bermunculan, sehingga persaingan antar mereka tidak dapat dihindarkan. Konsep one stop shopping yaitu suatu konsep dimana masyarakat dalam berbelanja ingin segera mendapatkan semua yang dibutuhkan dan diinginkannya saat itu juga dan dapat terpenuhi di tempat itu pula, sehingga dengan demikian waktu untuk berbelanja lebih singkat. Menurut Ma'ruf (2005:37) one stop shopping adalah suatu tempat berbelanja yang memenuhi semua kebutuhan individu dan keluarga.

Situasi persaingan yang seperti sekarang ini, penting bagi pihak swalayan untuk berlomba-lomba dalam memberikan kepuasan dalam bentuk yang 
relatif belum pernah diberikan oleh pesaingnya kepada konsumen. Agar dapat merebut simpati dan perhatian konsumen, pihak toko perlu untuk mengetahui lingkungan toko bagaimana yang harus diciptakan agar dapat membentuk kepuasan konsumen.

Pesatnya pertumbuhan pusat-pusat perbelanjaan baru mendorong pula jumlah toko berkonsep swalayan di Indonesia. Masing-masing toko atau swalayan berusaha untuk memberikan pelayanan terbaik kepada konsumennya, misalnya pengaturan tata letak barang yang memudahkan konsumen untuk menemukan beberapa barang yang dibutuhkannya, lokasi yang strategis, mudah dijangkau serta kondisi ruang yang memberikan rasa kenyamanan sehingga konsumen merasa betah untuk berbelanja.

Semakin kompleknya kebutuhan manusia yang harus dipenuhi, memaksa pemasar untuk meningkatkan mutu dari manajemen penjualan produknya. Sehingga muncul harapan perusahaan akan mampu bertahan atau bahkan memenangkan persaingan dalam dunia usaha. Saluran distribusi merupakan bagian dari manajemen pemasaran. Salah satu bagian dalam distribusi yang perlu diperhatikan oleh pemasar adalah lingkungan toko yang meliputi lokasi toko, tata letak toko dan atmosfer toko.

Dari beberapa pernyataan di atas, dapat ditarik pesan bahwa lingkungan toko dapat mendatangkan reaksi emosi tertentu dari konsumen misalnya: kesenangan dimana perasaan ini dapat mempengaruhi jumlah, waktu, dan uang yang dihabiskan sewaktu berbelanja. Untuk dapat sampai pada kepuasan konsumen, hal yang dapat dilakukan oleh pemasar adalah pemahaman terhadap konsep kepuasan itu sendiri. Perilaku yang ditunjukkan oleh konsumen akan mengarahkan pasar untuk memahami halhal yang dapat mempengaruhi kepuasan konsumen yang akhirnya pemahaman ini akan mempermudah jalan bagi pemasar untuk menciptakan suatu pengulangan pembelian atau loyalitas konsumen.

Konsumen hidup di dalam lingkungan yang kompleks dimana konsumen dituntut untuk dapat mengambil banyak keputusan membeli setiap harinya. Setiap keputusan yang diambil oleh konsumen tentunya berharap mendapatkan kepuasan dalam proses pembelian tersebut. Kepuasan konsumen menurut Kotler (2013:42) adalah perasaan senang atau kecewa seseorang yang muncul setelah membandingkan antara persepsi dan kesannya terhadap kinerja suatu produk dan harapan-harapannya. Toyin A. Clotte dkk (2008) dalam hasil penelitiannya menyebutkan, kualitas pelayanan, kualitas produk dan pengendalian citra merek loyalitas pelanggan yang diukur dengan kesediaan pelanggan untuk merekomendasikan produk pengecer kepada orang lain. 
Terciptanya kepuasan konsumen dapat memberikan beberapa manfaat, diantaranya adalah terciptanya hubungan yang harmonis antara perusahaan dan konsumen, memberikan dasar yang baik dalam keputusan pembelian lebih lanjut terciptanya loyalitas konsumen dan membentuk suatu rekomendasi dari mulut ke mulut (word of mouth) yang menguntungkan bagi perusahaan serta reputasi perusahaan menjadi lebih baik di mata konsumen. Kepuasan konsumen akan tercapai bila harapan atas produk tersebut terpenuhi. Kepuasan konsumen dapat dilihat dari rasa puas terhadap fasilitas fisik, kemudahan prosedur, kemauan karyawan dalam membantu konsumen, kemampuan pelayanan, perhatian konsumen dan harga yang ditawarkan.

Tata letak (store layout) dapat memberikan dampak yang besar bagi konsumen. Pada tingkat yang paling mendasar, tata letak mempengaruhi faktor-faktor seperti berapa lama konsumen akan berada dalam toko, berapa banyak produk yang mengalami kontak pandang dengan konsumen dan jalur mana dalam toko yang akan dilalui oleh konsumen. Faktor-faktor tersebut dapat mempengaruhi apa dan bagaimana suatu pembelian dilakukan. Penelitian dari Zohre Hosseini, Sreenivasan Jayashree \& Chinnasamy Malarvizhi (2014) dalam jurnal yang berjudul "Store Image and Its Effect on Customer Perception of Retail Stores" menyatakan bahwa menunjukan adanya hubungan signifikan dan positif antara Store Atmosphere, Musik, kualitas merchandise, pelayanan, dan Convenience dan persepsi pelanggan.

Penelitian dari Chris Lazaris, Adam Vrechopoulos dkk (2015) dalam jurnal yang berjudul "The Interplay Of Omniretailing \& Store Atmosphere On Consumer's Purchase Intention Towards The Physical Retail Store" meyatakan bahwa atmosfer toko dilihat dari sudut pandang pengguna online dan offline ternyata memiliki peranan yang sama pentingnya bagi konsumen dalam intensitas pembelian yang dilakukan oleh konsumen.

Swalayan sebagai salah satu bentuk usaha perniagaan eceran modern semakin tumbuh menjamur, seiring dengan meningkatnya kesejahteraan sosial ekonomi masyarakatnya. Tuntutan untuk mendapatkan semua kebutuhan dan keinginan terhadap produk dan jasa lebih baik, dimana kemudahan dan kenyamanan fasilitas serta pelayanan yang memuaskan mulai diperhitungkan.

\section{METODE PENELITIAN Jenis Penelitian}

Penelitian ini terdiri atas satu variabel bebas yaitu lingkungan toko (X) dan satu variabel terikat yaitu kepuasan konsumen (Y). Sedangkan variabel bebas $(\mathrm{X})$ terdiri atas tiga sub variabel yaitu lokasi toko $\left(\mathrm{X}_{1}\right)$, tata letak 
toko $\left(\mathrm{X}_{2}\right)$, dan atmosfer toko $\left(\mathrm{X}_{3}\right)$. Variabel terikat $(\mathrm{Y})$ dengan sub variabel kepuasan konsumen. Untuk lebih memahami hubungan antar variabel tersebut dapat dilihat pada gambar di bawah ini.

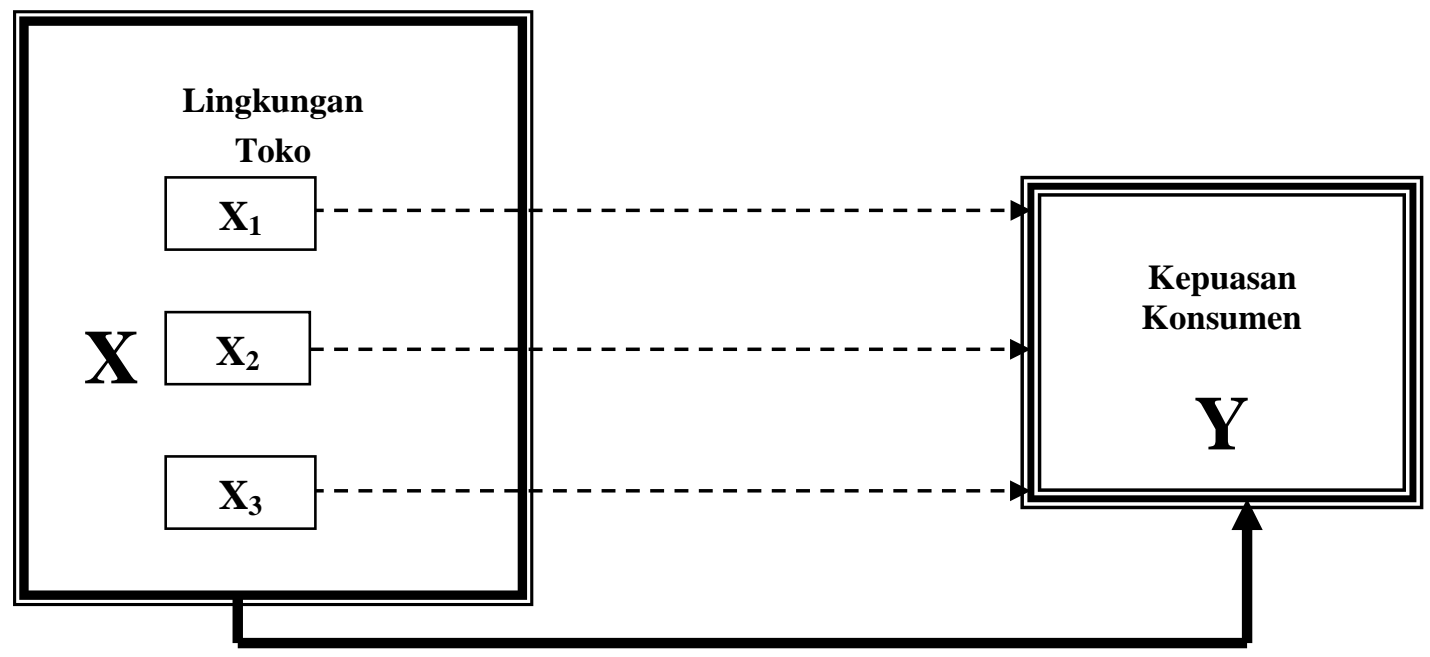

\section{Gambar 1. Rancangan Penelitian}

Keterangan Gambar:

$\mathrm{X} \quad=$ Lingkungan toko

$\mathrm{X}_{1} \quad=$ Lokasi toko

$\mathrm{X}_{2}=$ Tata letak toko

$\mathrm{X}_{3} \quad=$ Atmosfer toko

$\mathrm{Y} \quad=$ Kepuasan Konsumen

$--_{---. \rightarrow} \quad=$ Pengaruh variabel $\mathrm{X}$ terhadap $\mathrm{Y}$ secara parsial

$=$ Pengaruh variabel X terhadap Y secara simultan

Dari rancangan penelitian tersebut diatas menunjukkan bahwa kegiatan analisis data dilakukan melalui kegiatan menganalisis masing-masing sub variabel bebas dengan variabel terikat baik secara simultan maupun parsial. Selain menganalisis sub variabel bebas lokasi toko $\left(\mathrm{X}_{1}\right)$, tata letak toko $\left(\mathrm{X}_{2}\right)$, atmosfer toko $\left(\mathrm{X}_{3}\right)$ secara simultan dan parsial juga dilakukan analisis untuk mengetahui pengaruh yang dominan dari variabel bebas yang ada terhadap variabel terikat yaitu kepuasan konsumen.

\section{Populasi \& Sampel}

Dalam penelitian ini yang menjadi populasi adalah konsumen yang berbelanja di Swalayan modern pada kecamatan Mojoroto kota Kediri, Jawa Timur. Jumlah rata-rata konsumen tiap hari \pm 500 . Sehingga jika satu bulan jumlah konsumen rata-rata sebesar 15.000. Jumlah ini diperoleh dari data penjualan dan kepala toko Swalayan moderen. 
Teknik pengambilan sampel dari penelitian ini adalah sampel insidental atau accidental sample. jumlah sampel yang ditentukan dalam penelitian ini adalah 100 responden yang sedang berbelanja atau pernah berbelanja di Swalayan Moderen pada kecamatan Mojoroto Kota Kediri, Jawa Timur. Hal ini dilakukan dengan harapan sampel dapat mewakili populasi dengan pertimbangan keterbatasan waktu, tenaga, dan dana peneliti.

\section{Analisis Statistik Inferensial}

Tujuan analisis inferensial adalah untuk mengetahui pengaruh atau hubungan antara variabel bebas dengan variabel terikat baik secara parsial maupun simultan. Analisis data penelitian ini menggunakan analisis Regresi Berganda yang fungsinya adalah untuk mengetahui pengaruh secara bersama-sama (simultan) maupun sendiri-sendiri (parsial) antara variabel bebas $(\mathrm{X})$ dengan variabel terikat $(\mathrm{Y})$.

\section{Hipotesis}

Uji T. Untuk dikaji parsial dilakukan uji t (individual test) yang digunakan untuk mengetahui pengaruh dari tiap-tiap variabel bebas terhadap variabel terikat. Untuk menarik kesimpulan apakah hipotesis 1 dan 2 diterima atau ditolak, dengan cara membandingkan $t$ hitung dengan $t$ tabel atau bisa juga dengan memperhatikan signifikansi t lebih kecil atau sama dengan 0,05 atau lebih besar dari 0,05 .

Uji F. Uji pengaruh secara simultan menggunakan uji $F$ digunakan untuk mengetahui tingkat pengaruh variabel bebas secara bersama-sama terhadap variabel terikat.

\section{HASIL PENELITIAN}

\section{Analisis Statistik Deskritif}

\section{Lokasi Toko}

Lokasi toko diukur dengan menggunakan 5 indikator yaitu (1) akses, (2) visibilitas, (3) lalu lintas (traffic), (4) tempat parkir yang luas, dan (5) biaya menuju lokasi, yang kemudian dikembangkan menjadi 6 item pertanyaan yang diukur berdasarkan interval dengan skor 1-4. Sehingga diperoleh nilai harapan terendah 6 dan nilai harapan tertinggi 24. Rentangan (range) didapat dari nilai terbesar dikurangi nilai terendah $24-6=18$. Sedangkan besar kelas interval ditentukan berdasarkan data tersebut diperoleh nilai interval sebesar $18: 4=4,5$.

Penilaian responden atas lokasi toko pada Swalayan Moderen dapat dilihat dalam distribusi frekuensi sebagai berikut : 
Tabel 1. Distribusi Frekuensi Lokasi Toko

\begin{tabular}{ccccc}
\hline No. & Kriteria & Interval & f & \%f \\
\hline 1 & Sangat tidak setuju & $06,00-10,50$ & 0 & $0 \%$ \\
2 & Tidak Setuju & $10,51-15,00$ & 0 & $0 \%$ \\
3 & Setuju & $15,01-19,50$ & 56 & $56 \%$ \\
4 & Sangat setuju & $19,51-24,00$ & 44 & $44 \%$ \\
\hline \multicolumn{5}{c}{ T o t a l } \\
\hline
\end{tabular}

(Sumber: Data primer 2017)

Dari tabel diatas dapat diketahui bahwa $44 \%$ responden menyatakan sangat setuju dan $56 \%$ responden menyatakan setuju terhadap pemilihan lokasi yang dilaksanakan oleh Swalayan Moderen. Dari sini dapat dilihat bahwa secara umum pemilihan lokasi toko adalah baik, yang ditunjukkan dengan nilai sebesar $56 \%$ menyatakan setuju. Sehingga dapat disimpulkan bahwa rata-rata responden menyatakan setuju terhadap lokasi toko yang dilakukan Swalayan Moderen.

\section{Tata Letak Toko}

Tata letak toko diukur dengan menggunakan 6 indikator yaitu (1) desain pintu masuk, (2) jumlah pintu masuk/keluar, (3) desain bagian dalam (interior design), (4) bentuk tata letak, (5) penataan barang dagangan, dan (6) lalu lintas dalam toko, yang kemudian dikembangkan menjadi 7 item pertanyaan yang diukur berdasarkan interval dengan skor 1-4. Sehingga diperoleh nilai harapan terendah 7 dan nilai harapan tertinggi 28 . Rentangan (range) didapat dari nilai terbesar dikurangi nilai terendah $28-7=21$. Sedangkan besar kelas interval ditentukan berdasarkan data tersebut diperoleh nilai interval sebesar $21: 4=5,25$.

Penilaian responden atas tata letak toko pada Swalayan Moderen dapat dilihat dalam distribusi frekuensi sebagai berikut:

Tabel 2. Distribusi Frekuensi Tata Letak Toko

\begin{tabular}{ccccc}
\hline No. & Kriteria & Interval & f & \%f \\
\hline 1 & Sangat tidak setuju & $07,00-12,25$ & 0 & $0 \%$ \\
2 & Tidak Setuju & $12,26-17,50$ & 6 & $6 \%$ \\
3 & Setuju & $17,51-22,75$ & 50 & $50 \%$ \\
4 & Sangat setuju & $22,76-28,00$ & 44 & $44 \%$ \\
\hline \multicolumn{2}{r}{ T ot a l } & & 100 & $100 \%$ \\
\hline
\end{tabular}

(Sumber: Data primer, 2017)

Dari tabel diatas dapat diketahui bahwa $44 \%$ responden menyatakan sangat setuju, 50 $\%$ responden menyatakan setuju dan $6 \%$ responden menyatakan tidak setuju terhadap pemilihan tata letak toko yang dilaksanakan oleh Swalayan Moderen. Secara umum pemilihan tata letak toko adalah baik, ditunjukkan dengan nilai sebesar $50 \%$ menyatakan setuju. Namun ada beberapa responden yang menyatakan tata letak toko yang dilaksanakan Swalayan Moderen tidak baik, ditunjukkan dengan nilai sebesar $6 \%$ menyatakan tidak setuju.

\section{Atmosfer Toko}

Atmosfer toko diukur dengan menggunakan 5 indikator, (1) tata cahaya, (2) ketinggian langit-langit, (3) warna, (4) musik, dan (5) temperatur dalam toko, yang kemudian dikembangkan menjadi 7 item pertanyaan yang diukur berdasarkan interval dengan skor 1-4. Diperoleh nilai terendah 7 dan nilai tertinggi 28. Rentangan (range) didapat dari 
nilai terbesar dikurangi nilai terendah $28-7=21$. Kelas interval ditentukan berdasarkan data diperoleh nilai interval sebesar $21: 4=5,25$.

Tabel 3 . Distribusi Frekuensi Atmosfer Toko

\begin{tabular}{|c|c|c|c|c|}
\hline No. & Kriteria & Interval & f & \%f \\
\hline 1 & Sangat tidak setuju & $07,00-12,25$ & 0 & $0 \%$ \\
2 & Tidak Setuju & $12,26-17,50$ & 0 & $0 \%$ \\
3 & Setuju & $17,51-22,75$ & 54 & $54 \%$ \\
4 & Sangat setuju & $22,76-28,00$ & 46 & $46 \%$ \\
\hline \multicolumn{2}{|c|}{ T o t a I } & 100 & $100 \%$ \\
\hline
\end{tabular}

(Sumber: Data primer, 2017)

Dari tabel diatas dapat diketahui bahwa $46 \%$ responden menyatakan sangat setuju dan $54 \%$ responden menyatakan setuju terhadap pemilihan atmosfer toko yang dilaksanakan oleh Swalayan Moderen. Menunjukkan bahwa sebagian besar responden menyatakan setuju yang berarti memberikan penilaian baik, dapat dilihat dengan adanya nilai sebesar $54 \%$ menyatakan setuju. Sehingga dapat disimpulkan bahwa rata-rata responden menyatakan setuju dengan atmosfer toko yang dilakukan Swalayan Moderen.

\section{Kepuasan Konsumen}

Penilaian responden atas kepuasan konsumen pada Swalayan Moderen dapat dilihat dalam distribusi frekuensi sebagai berikut:

Tabel 4 . Distribusi Frekuensi Kepuasan Konsumen

\begin{tabular}{|c|c|c|c|c|}
\hline No. & Kriteria & Interval & f & $\% \mathbf{f}$ \\
\hline 1 & Sangat tidak setuju & $10,00-17,50$ & 0 & $0 \%$ \\
\hline 2 & Tidak Setuju & $17,51-25,00$ & 0 & $0 \%$ \\
\hline 3 & Setuju & $25,01-32,50$ & 55 & $55 \%$ \\
\hline 4 & Sangat setuju & $32,51-40,00$ & 45 & $45 \%$ \\
\hline \multicolumn{3}{|c|}{ Tot a l } & 100 & $100 \%$ \\
\hline
\end{tabular}

(Sumber: Data primer, 2016)

Dari tabel diatas dapat diketahui bahwa $45 \%$ responden menyatakan sangat setuju dan $55 \%$ responden menyatakan setuju terhadap kepuasan konsumen pada Swalayan Moderen. Dari sini dapat dilihat bahwa sebagian besar memberikan nilai baik terhadap kepuasan konsumen yang ditunjukkan dengan adanya nilai sebesar 55\% menyatakan setuju. Sehingga dapat disimpulkan bahwa rata-rata responden menyatakan setuju atau memberikan nilai baik/puas.

\section{Analisis Statistik Inferensial}

Dari hasil regresi linier berganda didapatkan konstanta sebesar 7,949. Dan diketahui pula bahwa nilai $\beta$ untuk variabel $X_{1}$ sebesar 0,590 , nilai $\beta$ untuk variabel $X_{2}$ sebesar 0,241 , nilai $\beta$ untuk variabel $X_{3}$ sebesar 0,343 , dengan demikian dapat dihasilkan persamaan regresi sebagai berikut:

$$
\mathrm{Y}=7,949+0,590 \mathrm{X}_{1}+0,241 \mathrm{X}_{2}+0,343 \mathrm{X}_{3}
$$

Persamaan regresi tersebut berarti bahwa jika tidak ada $\mathrm{X}_{1}, \mathrm{X}_{2}, \mathrm{X}_{3}$, maka nilai $\mathrm{Y}$ adalah 7,949. Selanjutnya jika koefisiensi regresi $\left(X_{1}\right)$ naik satu satuan, maka koefisiensi $(Y)$ akan naik sebesar 0,590, dengan asumsi bahwa $\mathrm{X}_{2}, \mathrm{X}_{3}$ konstan. Jika koefisiensi regresi $\left(\mathrm{X}_{2}\right)$ naik satu satuan, maka koefisiensi (Y) akan naik sebesar 0,241, dengan asumsi 
bahwa $X_{1}, X_{3}$ konstan. Jika koefisiensi regresi $\left(X_{3}\right)$ naik satu satuan, maka koefisiensi (Y) akan naik sebesar 0,343 , dengan asumsi bahwa $\mathrm{X}_{1}, \mathrm{X}_{2}$, konstan.

\section{Pengujian Hipotesis (Uji t)}

Tabel 5. Pengaruh Secara Parsial Antara Lingkungan Toko

Terhadap Kepuasan Konsumen

\begin{tabular}{|c|c|c|c|c|c|}
\hline Variabel Bebas & $\begin{array}{c}\text { Variabel } \\
\text { Terikat }\end{array}$ & B & t hitung & Sig & Hipotesis \\
\hline Lokasi toko & Kepuasan & 0,590 & 4,622 & 0,000 & Ha diterima, Ho ditolak \\
\hline Tata letak toko & konsumen & 0,241 & 2,428 & 0,017 & Ha diterima, Ho ditolak \\
\hline Atmosfer toko & & 0,343 & 3,489 & 0,001 & Ha diterima, Ho ditolak \\
\hline
\end{tabular}

(Sumber: Data Primer, 2017)

\section{Pengaruh Lokasi Toko $\left(\mathrm{X}_{1}\right)$ terhadap Kepuasan Konsumen $(\mathrm{Y})$}

Dari hasil analisis data diperoleh nilai $\mathrm{t}_{\text {hitung }}=4,622$ dengan nilai signifikansi 0,000 . Untuk mengetahui diterima atau ditolaknya hipotesis dengan memperhatikan nilai signifikansi $\mathrm{t}=0,000$ yang berarti $<0,05$, maka dapat disimpulkan bahwa Ho yang berbunyi tidak ada pengaruh yang signifikan antara lokasi toko secara parsial terhadap kepuasan konsumen dalam berbelanja di Swalayan Moderen ditolak. Sedangkan Ha yang berbunyi ada pengaruh yang signifikan antara lokasi toko secara parsial terhadap kepuasan konsumen dalam berbelanja. Dengan demikian dapat dikatakan bahwa kepuasan konsumen dalam berbelanja dipengaruhi oleh variabel lokasi toko.

\section{Pengaruh Tata Letak Toko $\left(\mathrm{X}_{2}\right)$ terhadap Kepuasan Konsumen ( $\left.\mathrm{Y}\right)$}

Dari hasil analisis data diperoleh nilai $\mathrm{t}_{\text {hitung }}=2,428$ dengan nilai signifikansi 0,009 . Untuk mengetahui diterima atau ditolaknya hipotesis dengan memperhatikan nilai signifikansi $\mathrm{t}=0,017$ yang berarti $<0,05$, maka dapat disimpulkan bahwa Ho yang berbunyi tidak ada pengaruh yang signifikan antara tata letak toko secara parsial terhadap kepuasan konsumen dalam berbelanja ditolak. Sedangkan Ha yang berbunyi ada pengaruh yang signifikan antara tata letak toko secara parsial terhadap kepuasan konsumen dalam berbelanja diterima. Dengan demikian dapat dikatakan bahwa kepuasan konsumen dalam berbelanja di Swalayan Moderen dipengaruhi oleh variabel tata letak toko.

\section{Pengaruh Atmosfer Toko $\left(\mathrm{X}_{3}\right)$ terhadap Kepuasan Konsumen ( $Y$ )}

Dari hasil analisis data diperoleh nilai $\mathrm{t}_{\text {hitung }}=3,489$ dengan nilai signifikansi 0,016 . Untuk mengetahui diterima atau ditolaknya hipotesis dengan memperhatikan nilai signifikansi $\mathrm{t}=0,001$ yang berarti $<0,05$, maka dapat disimpulkan bahwa Ho yang berbunyi tidak ada pengaruh yang signifikan antara atmosfer toko secara parsial terhadap kepuasan konsumen dalam berbelanja. Sedangkan Ha yang berbunyi ada pengaruh yang signifikan antara atmosfer toko secara parsial terhadap kepuasan konsumen dalam berbelanja. Dengan demikian dapat dikatakan bahwa kepuasan konsumen dalam berbelanja dipengaruhi oleh variabel atmosfer toko. 


\section{Pengujian Hipotesis (Uji F)}

Tabel 6. Pengaruh Secara Simultan Antara Lingkungan Toko Terhadap Kepuasan Konsumen

\begin{tabular}{llccc}
\hline \multicolumn{1}{c}{ Variabel Bebas } & Variabel Terikat & F hitung & Sig & Hipotesis \\
\hline $\begin{array}{l}\text { Lokasi toko } \\
\text { Tata letak toko }\end{array}$ & $\begin{array}{l}\text { Kepuasan } \\
\text { Atmosfer toko }\end{array}$ & 86,482 & 0,000 & $\begin{array}{l}\text { Ho ditolak, Ha } \\
\text { diterima }\end{array}$ \\
\hline
\end{tabular}

\section{Konstanta = 7,949 $\quad R=0,854 \quad R$ square=0,730 $\quad$ Adjusted R square $=0,721 \quad \alpha=0,05$}

(Sumber: Data Primer, 2017)

Dari hasil analisis data diperoleh nilai $\mathrm{F}_{\text {hitung }}=86,482$ dengan tingkat signifikansi 0,000. Untuk mengetahui diterima atau ditolaknya hipotesis dapat membandingkan nilai $\mathrm{F}_{\text {hitung }}=86,482$ dengan $\mathrm{F}_{\text {tabel }}$ sehingga diperoleh $\mathrm{F}_{\text {hitung }}>\mathrm{F}_{\text {tabel }}$ atau dengan memperhatikan nilai signifikansi $\mathrm{F}=0,000$ yang berarti $<0,05$, maka dapat disimpulkan bahwa Ho yang berbunyi tidak ada pengaruh yang signifikan antara lokasi toko, tata letak toko, dan atmosfer toko secara simultan terhadap kepuasan konsumen dalam berbelanja ditolak, sedangkan Ha yang berbunyi ada pengaruh yang signifikan antara lokasi toko, tata letak toko, dan atmosfer toko secara simultan terhadap kepuasan konsumen dalam berbelanja diterima.

Dengan demikian dapat dikatakan bahwa kepuasan konsumen dalam berbelanja dipengaruhi oleh variabel lokasi toko, tata letak toko, dan atmosfer toko. Adjusted R Square digunakan untuk mengetahui besarnya variabel terikat yang bisa dijelaskan secara simultan oleh variabel bebas. Digunakan Adjusted R Square karena variabel bebas lebih dari 2 serta memiliki satuan yang berbeda-beda. Diketahui nilai Adjusted $\mathrm{R}$ Square sebesar 0,721 dapat diartikan bahwa variabel lingkungan toko dalam mempengaruhi kepuasan konsumen dalam berbelanja adalah sebesar $72,1 \%$, sedangkan sisanya $27,9 \%$ dipengaruhi hal-hal lain yang tidak dijelaskan dalam penelitian ini.

Dari hasil analisis regresi berganda dapat dilhitung nilai sumbangan efektif masingmasing variabel seperti pada tabel berikut:

Tabel 7. Hasil Perhitungan Sumbangan Efektif

\begin{tabular}{|c|c|c|}
\hline Variabel & Koef. Beta x Koef. r & $\mathrm{SE}(\%)$ \\
\hline Lokasi Toko $\left(\mathrm{X}_{1}\right)$ & $0,463 \times 0,821$ & $38,01 \%$ \\
\hline Tata Letak Toko $\left(\mathrm{X}_{2}\right)$ & $0,217 \times 0,747$ & $16,20 \%$ \\
\hline Atmosfer Toko $\left(\mathrm{X}_{3}\right)$ & $0,261 \times 0,717$ & $18,71 \%$ \\
\hline \multicolumn{2}{|c|}{ Total } & $72,92 \%$ \\
\hline
\end{tabular}

(Sumber: Data Primer, 2017)

Berdasarkan hasil perhitungan sumbangan efektif diatas, dapat diketahui bahwa diantara variabel bebas (lokasi toko, tata letak toko dan atmoesfer toko) yang dominan pengaruhnya terhadap kepuasan konsumen dalam berbelanja adalah variabel lokasi 
toko. Hal tersebut dapat dilihat dari nilai sumbangan efektif lokasi toko yang lebih besar dari nilai sumbangan efektif variabel lainnya, yaitu sebesar $38,01 \%$.

\section{KESIMPULAN DAN SARAN \\ Kesimpulan}

Berdasarkan hasil penelitian dan pembahasan dari hasil analisis data, maka dapat ditarik beberapa kesimpulan sebagai berikut: (1) Terdapat pengaruh yang signifikan antara lokasi toko yang terdiri dari akses, visibilitas, lalu lintas, tempat parkir yang luas dan biaya untuk mencapai lokasi terhadap kepuasan konsumen dalam berbelanja di Swalayan Moderen. Secara keseluruhan menyatakan bahwa rata-rata responden memberikan penilaian puas terhadap lokasi toko yang dilaksanakan oleh Swalayan Moderen; (2) Terdapat pengaruh yang signifikan antara tata letak toko yang terdiri dari desain pintu masuk, jumlah pintu masuk/keluar, desain bagian dalam, bentuk tata letak, penataan barang dagangan (display) dan lalu lintas orang dalam toko terhadap kepuasan konsumen dalam berbelanja di Swalayan Moderen. Secara keseluruhan menyatakan bahwa rata-rata responden memberikan penilaian puas terhadap tata letak toko yang dilaksanakan oleh Swalayan Moderen; (3) Terdapat pengaruh yang signifikan antara atmosfer toko yang terdiri dari tata cahaya, ketinggian langit-langit, warna, musik dan temperatur dalam toko terhadap kepuasan konsumen dalam berbelanja di Swalayan Moderen. Secara keseluruhan menyatakan bahwa rata-rata responden memberikan penilaian puas terhadap atmosfer toko yang dilakukan oleh Swalayan Moderen; (4) Terdapat pengaruh yang signifikan antara lokasi toko, tata letak toko dan atmosfer toko secara simultan terhadap kepuasan konsumen dalam berbelanja di Swalayan Moderen. Berdasarkan penilaian responden menyatakan bahwa rata-rata konsumen yang berbelanja di Swalayan Moderen masih memperhatikan adanya lingkungan toko yang meliputi lokasi toko, tata letak toko dan atmosfer toko; dan (5) Variabel lokasi toko merupakan variabel yang dominan pengaruhnya terhadap kepuasan konsumen dalam berbelanja di Swalayan Moderen. Kesimpulan tersebut didasarkan pada hasil pengujian SE (Sumbangan Efektif) yang menunjukkan nilai variabel lokasi toko mempunyai nilai yang paling besar.

\section{Saran}

Berdasarkan atas dasar temuan penelitian, maka peneliti dapat memberikan beberapa saran yang diharapkan mampu memberikan sumbangan pikiran dan menjadi bahan pertimbangan bagi pihak toko dalam rangka meningkatkan perbaikan di masa yang akan datang, antara lain: (1) Warna ruangan yang didominasi warna putih memang sudah cukup baik dan terlihat bersih, namun masih perlu penambahan warna hangat yang mampu menarik perhatian konsumen seperti warna kuning; dan (2) Untuk penelitian selanjutnya sebaiknya menambahkan faktor yang lain seperti harga dan kualitas produk yang dapat mempengaruhi kepuasan konsumen dalam berbelanja. 


\section{DAFTAR RUJUKAN}

Arikunto, S. 2002. Prosedur Penelitian: Suatu Pendekatan Praktek. Edisi Revisi V. Jakarta: PT Rineka Cipta.

Cahyanti, A. 2005. Pengaruh Tata Ruang Toko Terhadap Kepuasan Konsumen Dalam Berbelanja di Swalayan surya Ponorogo. Skripsi tidak diterbitkan. Malang: Program Sarjana Fakultas Ekonomi Universitas Negeri Malang.

Clotte, A T, . Collie, A D., Stodnick, M. 2008. Drivers Of Customer Loyalty In A Retail Store Environment. Ohio. Journal of Service Science - Third Quarter.

Ferrel, O., \& Pride, W. 1987. Pemasaran: Teori dan Praktik Sehari-hari, Jilid 1, Edisi Ketujuh. Terjemahan oleh Daniel Wijaya. 1995. Jakarta: Binarupa Aksara.

Kotler, P. 2013. Manajemen Pemasaran Buku 1. Jakarta: Indeks

Ma'ruf, H. 2005. Pemasaran Ritel. Jakarta: PT Gramedia Pustaka Utama.

McCarthy, J. \& Perrault, W. 1995. Pemasaran: Sebuah Ancangan Manajerial Global. Jakarta: Binarupa Aksara.

Peter, J. P., \& Olson, J. C. 2000. Perilaku Konsumen dan Strategi Pemasaran, Edisi 4, Jilid 2. Terjemahan oleh Damos Sihombing. 2000. Jakarta: Erlangga.

Rangkuti, F. 2002. Riset Pemasaran. Jakarta: PT. Gramedia Pustaka Utama bekerja sama dengan Sekolah Tinggi Ekonomi IBII.

Sistaningrum, W. 2002. Manajemen Penjualan Produk. Yogyakarta: Kanisius.

Sugiyono. 2004. Metode Penelitian Bisnis. Bandung: CV. Alfabeta.

Tjiptono, F. 2016. Pemasaran dan Aplikasinya. Yogyakarta: Andi. 